\title{
Memahami desain metode penelitian kualitatif
}

\author{
Muhammad Rijal Fadli \\ Universitas Negeri Yogyakarta, Indonesia \\ Email: rijalfadli.co@gmail.com
}

\begin{abstract}
Abstrak
Tujuan artikel ini untuk memahami desain metode penelitian kualitatif. Metode yang digunakan adalah studi pustaka (library research), pengumpulan data dengan cara mencari sumber dan merkontruksi dari berbagai sumber seperti buku, jurnal, dan riset-riset yang sudah ada. Hasilnya bahwa penelitian kualitatif dilakukan dengan desain penelitian yang temuan-temuannya tidak didapatkan melalui prosedur statistik atau dalam bentuk hitungan, melainkan bertujuan mengungkapkan fenomena secara holistik-kontekstual dengan pengumpulan data dari latar/ setting alamiah dan memanfaatkanpeneliti sebagai instrument kunci. Penelitian kualiatif memiliki sifat deskriptif dan cenderung menggunakan analisis pendekatan induktif, sehingga proses dan makna berdasarkan perspektif subyek lebih ditonjolkan dalam penelitian kualitatif ini. Desain penelitian kualitatif ini dapat dijadikan sebagai metode dalam penelitian, karena desainnya dijabarkan secara komprehensif yang mudah untuk dipahami oleh kalangan peneliti dan akademisi.
\end{abstract}

Kata Kunci: Desain, Penelitian, Kualitatif.

\section{Abstract}

The purpose of this article is to understand the design of qualitative research methods. The method used is library research, data collection by searching for sources, and reconstruction from various sources such as books, journals, and existing researches. The 
result is that qualitative research is conducted with a research design where the findings are not obtained through statistical procedures or in the form of calculations, but rather aim to reveal phenomena in a holistic-contextual manner by collecting data from natural settings and utilizing the researcher as a key instrument. Qualitative research has a descriptive nature and tends to use an inductive approach analysis so that the process and meaning based on the subject's perspective are emphasized more in this qualitative research. This qualitative research design can be used as a method in research because the design is described in a comprehensive manner that is easy to understand by researchers and academics.

Keywords: Design, Research, Qualitative.

\section{Pendahuluan}

Penelitian termasuk bagian penting dari suatu pengetahuan guna memainkan peran penting dalam pembangunan ilmu pengetahuan. Bungin (2001) menguraikan, bahwa penelitian menempatkan posisi yang paling urgen di dalam ilmu pengetahuan, artinya untuk mengembangkan dan melindunginya dari kepunahan. Dalam hal ini, fungsi penelitian mempunyai kemampuan untuk meng-upgrade ilmu pengetahuan sehingga tetap up-to-date, canggih, aplicated, dan aksiologis bagi masyarakat.

Ilmu pengetahuan terus berkembang, sejalan dengan perkembangan peradaban manusia. Selama manusia itu masih hidup dan berkembang di muka bumi ini, maka banyak ragam fenomena baru yang akan terjadi. Untuk memahami berbagai fenomena baru memang sangat diperlukan ilmu pengetahuan baru yang dilahirkan melalui penelitian dengan menggunakan metodologi yang tepat. Dengan demikian posisi metode penelitian kualitatif sangat dibutuhkan dalam rangka perkembangan ilmu pengetahuan.

Melalui penelitian kualitatif Basrowi \& Suwandi (2008: 2) menuturkan bahwa peneliti dapat mengenali subjek, merasakan apa yang dialami subjek dalam kehidupan sehari-hari. Penelitian kualitatif di dalamnya melibatkan peneliti sehingga akan paham mengenai konteks dengan situasi dan setting fenomena alami sesuai yang sedang diteliti. Dari setiap fenomena merupakan sesuatu yang unik, berbeda dengan yang lainnya karena berbeda konteksnya. Tujuan dari penelitian kualitatif adalah untuk memahami kondisi suatu konteks dengan mengarahkan pada pendeskripsian secara rinci dan mendalam mengenai potret kondisi dalam suatu konteks yang alami (natural setting), tentang apa yang sebenarnya terjadi menurut apa adanya yang di lapangan studi. 
Penelitian dari Yusanto (2019) bahwa penelitian kualitatif memiliki ragam pendekatannya tersendiri, sehingga para peneliti dapat memilih dari ragam tersebut untuk menyesuaikan objek yang akan ditelitinya. Lebih lanjut Yulianty \& Jufri (2020), dalam penelitian kualitatif analisis data harus dilakukan dengan teliti agar data-data yang sudah diperoleh mampu dinarasikan dengan baik, sehingga menjadi hasil penelitian yang layak. Sedangkan dalam artikel ini, ingin mengkaji secara komprehensif dalam memahami desain penelitian kualitatif mulai dari pengkonsepan sampai pada pengkodean hasil data-data yang sudah diperoleh, inilah yang menjadi tujuan dalam artikel ini.

\section{Metode}

Metode artikel ini menggunakan studi pustaka (library research) yaitu metode pengumpulan data dengan cara memahami dan mempelajari teoriteori dari berbagai literatur yang berhubungan dengan penelitian. Menurut Zed (2004) ada empat tahap studi pustaka yaitu menyiapkan perlengkapan alat yang diperlukan, menyiapkan bibliografi kerja, mengorganisasikan waktu dan membaca serta mencatat bahan penelitian. Pengumpulan data dengan cara mencari sumber dan merkontruksi dari berbagai sumber seperti buku, jurnal, dan riset-riset yang sudah ada. Metode analisis menggunakan analisis conten dan analisis deskriptif. Bahan pustaka yang didapat dari berbagai referensi dianalisis secara kritis dan mendalam agar dapat mendukung proposisi dan gagasan.

\section{Hasil dan Pembahasan}

\section{Memahami Desain Penelitian Kualitatif}

Penelitian kualitatif adalah suatu proses penelitian untuk memahami fenomena-fenomena manusia atau sosial dengan menciptakan gambaran yang menyeluruh dan kompleks yang dapat disajikan dengan kata-kata, melaporkan pandangan terinci yang diperoleh dari sumber informan, serta dilakukan dalam latar setting yang alamiah (Walidin, Saifullah \& Tabrani, 2015: 77).

Penelitian kualitatif adalah penelitian yang dilakukan dengan setting tertentu yang ada di dalam kehidupan riil (alamiah) dengan maksud menginvestigasi dan memahami fenomena: apa yang terjadi, mengapa terjadi, dan bagaimana terjadinya? Artinya riset kualitatif berbasis pada konsep going exploring yang melibatkan in-depth and case-oriented study atau sejumlah kasus 
atau kasus tunggal (Chariri, 2009: 9). Sejalan dengan Denzin \& Lincoln (1994) penelitian kualitatif merupakan penelitian menggunakan latar alamiah dengan maksud menafsirkan sebuah fenomena yang terjadi dan dilakukan dengan jalan melibatkan berbagai metode yang ada. Penelitian kualitatif berusha untuk menemukan dan menggambarkan secara naratif kegiatan yang dilakukan dan dampak dari tindakan yang dilakukan terhadap kehidupan mereka.

Penelitian kualitatif berlandaskan kepada filsafat post-positivisme, sebab berguna untuk meneliti pada obyek yang alamiah, (sebagai lawannya eksperimen) peneliti berkontribusi sebagai instrument kunci, pengambilan sampel, sumber data dilakukan dengan purposive dan snowball, teknik pengumpulan dengan trianggulasi (gabungan), analisis data bersifat induktif/kualitatif, dan hasil penelitian kualitatif lebih menekankan makna dari pada generalisasi (Sugiyono, 2011: 299). Karena tujuan utama dalam penelitian kualitatif untuk membuat fakta/fenomena agar mudah dipahami (understandable) dan memungkinkan sesuai modelnya dapat menghasilkan hipotesis baru (Hennink, Hutter \& Bailey, 2020; Sarmanu, 2017).

Dengan demikian, penelitian kualiatatif bertujuan untuk mendapatkan pemahaman yang mendalan mengenai masalah-masalah manusia dan sosial, bukan mendeskripsikan bagian permukaan dari sebuah realitas sebagaimana dilakukan penelitian kuantitatif dengan positivismenya. Karena peneliti menginterpretasikan bagaimana subjek memperoleh makna dari lingkungan sekeliling, dan bagaimana makna tersebut mempengaruhi perilaku mereka. Penelitian dilakukan dalam latar (setting) yang alamiah (naturalistic) bukan hasil perlakuan (treatmen) atau manipulasi variable yang dilibatkan.

Tujuan penelitian kualitatif dapat dilihat dari: (1) Penggambaran obyek penelitian (desricbing object); agar obyek penelitian dapat dimaknai maka perlu digambarkan melalui cara memotret, memvideo, meilustrasikan dan menarasikan. Penggambaran ini dapat dilakukan terhadap obyek berupa peristiwa, interaksi sosial, aktivitas sosial religious, dan sebagainya. (2) Mengungkapkan makna di balik fenomena (exploring meaning behind the phenomena); makna dibalik fenomena/fakta dapat diungkap bila peneliti memperlihatkan dan mengunkapkan melalui wawancara mendalam (dept interview) dan observasi berpartisipasi (participation observation). (3) Menjelaskan fenomena yang terjadi (explaning object); fenomena yang tampak di lapangan terkadang tidak sama dengan apa yang menjadi tujuan, menjadi inti persolan atau dengan kata lain yang tampak berbeda dengan maksud utama, sehingga perlu adanya penjelasan secara detail, rinci dan sistematis (Setiawan \& Anggito, 
2018: 39). Klarifikasi secara obyektif perlu dilakukan untuk menghindari kesalahan konsepsi (miscon-ceotuion), kesalahpahaman (misunderstanding), dan kesalahan interpretasi (misinterpretation) (Suwendra, 2018: 5; Merriam \& Grenier, 2019).

Karakteristik penelitian kualitatif, seorang peneliti sebelum melakukan proses penelitian, perlu mengenal dan memahami tentang karakteristik penelitian kualitatif dengan harapan dapat mempermudah saat proses penelitian dan dapat mengungkap informasi kualitatif secara teliti dalam prosesnya yang deskripsi-analisis dan penuh makna. Penelitian kualitatif dilakukan dengan karakteristik yang mendeskripsikan fakta atau suatu keadaan yang sebenarnya, namun laporan yang dibuat harus memperhatikan interpretasi ilmiah agar bagus hasilnya. Bogdan \& Biklen (1982: 27-29); Frankel \& Wallen (1998: 379 . 401), menguraikan bahwa karakteristik kualitatif yaitu: (1) Latar yang alamiah (naturistic inquiry), (2) Peneliti adalah sebagai instrument kunci, (3) Bersifat deskriptif, (4) Penelitian kualitatif lebih menekankan terhadap proses daripada hasil/autcome, (5) Analisis data dilakukan secara induktif, dan (6) Penelitian kualitatif lebih menekankan makna.

Penelitian kualitatif ini tentunya berbeda dengan penelitian kuantitatif, sebab penelitian kualitatif tidak menggunakan statistic, namun melalui pengumpulan data, analisis, lalu diinterpretasikan. Biasanya familiar dengan hubungan masalah sosial dan manusia yang bersifat interdisipliner, fokus pada multimetod, natrualistik dan interpretative (Creswell, 1994). Penelitian kualitatif fokus pada penekanan pemahaman tentang masalah-masalah dalam kehidupan sosial berdasarkan kondisi realistis atau natural setting yang holistik, kompleks, dan rinci. Berikut deskripsi perbedaan penelitian kuantitatif dengan kualitatif:

Tabel 1. Perbedaan Penelitian Kuantitatif dan Kualitatif

\begin{tabular}{cc}
\hline Penelitian Kuantitatif & Penelitian Kualitatif \\
\hline Measure objective facts & Contruct social reality, culture meaning \\
\hline Focus on variables & Focus on interactive process, event \\
\hline Reliability is key & Aunthenticity is key \\
\hline Value free & Values are presents and explicit \\
\hline Theory and data are separate & Theory and data are fused \\
\hline
\end{tabular}




\begin{tabular}{cc}
\hline Penelitian Kuantitatif & Penelitian Kualitatif \\
\hline Independent of context & Situationally constrained \\
\hline Many cases, subjects & Faw cases, subjects \\
\hline Statistical analysis & Thematic analysis \\
\hline Researcher is detached & Researcher is involved \\
\hline
\end{tabular}

Sumber: Neuman (2006).

Antara penelitian kuantitatif dan kualitatif tidak ada yang paling baik, sebab masing-masing dari penelitian tersebut memiliki sisi kelebihan dan kekurangannya. Artinya peneliti dapat menentukan/memilih metode mana yang tepat berdasarkan pada tujuan dan topik dari penelitian yang akan dilaksanakan. Akan tetapi, seiring perkembangan zaman, penggunakan kualitatif dan kuantitatif dapat/bisa digabungkan menjadi metode dalam memecahkan fenomena-fenomena baru yang dapat disebut dengan metode penelitian mix method (Suryani \& Hendryadi, 2015; Mamik, 2015).

Pendekatan-pendekatan penelitian dalam kualitatif ada beberapa macam diantaranya adalah fenomenology, etnografi, hermeneutik, grounded theory, naratif/historis, dan studi kasus. (1) Fenomenology; pendekatan ini berusaha untuk mengungkap, mempelajari serta memahami fenomena dan konteksnya yang khas dan uni dialami oleh individu hingga tataran keyakinan individu yang bersangkutan. Martin Heidegger mengembangkan pendekatan ini bertujuan untuk memahami atau mempelajari pengalaman hidup manusia, mencari hakikat atau esensi dari pengalaman dan sasarannya adalah untuk memahami pengalaman sebagaimana disadari. (2) Etnografi; pendekatan ini fokus pada riset sosial (budaya dan bahasa), menurut Creswell (2008: 473) "Etnographic designs are qualitative research procedures for describing, analyzing, and interpreting a culture-sharing group's shared patterns of behavior, beliefs, and language that develop over time". (3) Hermeneutik; "Hermeneutics as the methodology of interpretation can provide guidance for solving problems of interpretation of human actions, texts and other meaningful material by offering a toolbox based on solid empirical evidence" Ramberg \& Gjesdal (2014). Penafsiran untuk mengerti dan memahami arti terdalam dari informasi yang disampaikan oleh partisipan, hermeneutika juga mensyaratkan pemahaman konteks yang benar sehingga arti asli dapat terungkap dengan jelas dan benar, asumsi hermeneutika bahwa semua ilmu dan kegiatan belajar bersifat empiris. 


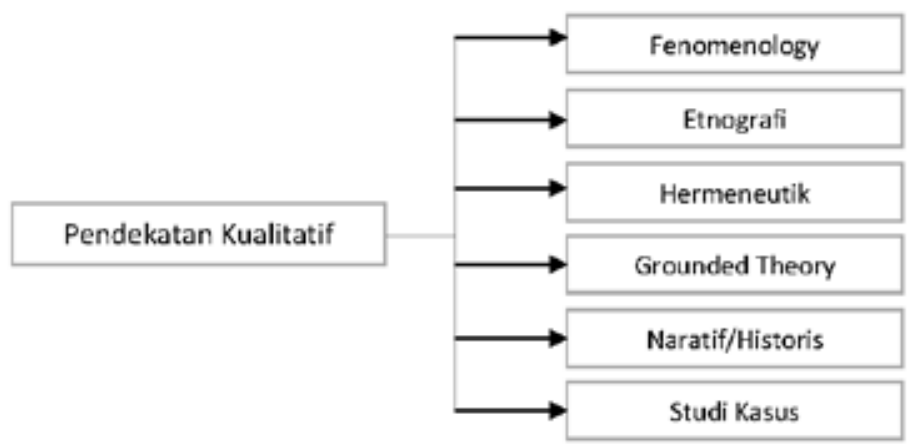

\section{Gambar 1. Pendekatan Penelitian Kualitatif}

(4) Grounded theory; Martin \& Turner (1986) "grounded theory an inductive, theory discovery methodology that allows the researcher to develop a theoretical account of the general features of a topic while simultaneously grounding the account in empirical observations of data". Artinya bahwa GT ini merupakan pendekatan untuk menganalisis yang terkait dengan data sistematis yang diterapkan dan menggunakan serangkaian metode untuk menghasilkan teori induktif mengenai area substantif. (5) Naratif/Historis; suati metode di dalam riset ilmu sosial, untuk membantu memahami identitas dan pandangan dunia seseorang dengan mengacu pada cerita-cerita (narasi) yang didengarkan/dituturkan. Dapat dikatakan juga sebagai proses penyelidikan secara kritis terhadap peristiwa masa lalu dan menghasilkan deskripsi/narasi serta penafsiran yang tepat, benar mengenai peristiwa-peristiwa. Biasanya teknik yang gunakan adalah heuristik, kritik sumber, interpretasi, dan historiografi (Daliman, 2014). (6) Studi kasus (case study); pendekatan yang dilakukan secara intensif, terinci dan mendalam mengenai suatu hal yang diteliti baik berupa program, peristiwa, aktivitas dan lainnya untuk memperoleh pengetahuan/informasi secara mendalam tentang hal tersebut (Baxter \& Jack, 2008). Fenomena yang dipilih biasanya disebut dengan kasus, artinya hal yang actual (real-life events), sedang berlangsung bukan sesuatu yang sudah lewat.

Dengan demikian, bahwa pendekatan apapun yang digunakan dalam penelitian kualitatif peneliti harus dapat memperhatikan dan memahaminya agar dalam mengungkap dan menggali subjek penelitiannya lebih tepat dan 
cocok sehingga hasilnya sesuai dengan tujuannya. Peran peneliti dalam menentukan pendekatan harus dapat sesuai dengan kondisi di lapangan, disisi lain peneliti juga harus memperhatikan pendekatan yang ideal dan bersifat tetap, teknik juga bersifat situasional/fleksibel, dan perubahan tetap dimungkinkan, bilamana semua yang dipersiapkan oleh peneliti kurang sesuai atau belum cocok. Ibaratkan seperti orang memancing; ukuran mata kail harus sudah ditentukan dari awal mengenai jenis/ukuran ikan apa yang akan didapatkan atau ikan yang ada diperarain tersebut, tetapi umpan yang dapat diganti/ditukar (mata pancing adalah pendekatan, umpan adalah tekniknya; wawancara dsb).

Setiap kegiatan penelitian pastinya harus selalu mengikuti suatu proses secara bertahap. Creswel (2008) telah menyajikan tahapan khusus penelitian kualitatif diantaranya yaitu (1) Identifikasi masalah; peneliti harus memulai apa yang menjadi sasaran penelitian, artinya menyangkut spesifikasi isu/fenomena yang hendak dipelajari/diteliti. (2) Literature riview (penelusuran pustaka); bagian ini peneliti harus mencari bahan atau sumber bacaan yang terkait fenomena yang akan diteliti, sehingga peneliti harus dapat menemukan kebaruan (novelty) atau kelebihan dari penelitianya dengan penelitian sebelumnya. (3) Menentukan tujuan penelitian; peneliti harus mengidentifikasi maksud/tujuan utama dari penelitiannya. (4) Pengumpulan data; peneliti harus memperhatikan dalam memilih dan menentukan objek/partisipan yang potensial, guna menjangkau kemampuan partisipan untuk terlibat secara aktif dalam penelitian. (5) Analisis dan interpretasi data (interpretation); data yang telah diperoleh oleh peneliti kemudian dianalisis atau ditafsirkan sehingga menghasilkan gagasan atau teori baru. (6) Pelaporan; peneliti membuat laporan hasil penelitiannya dengan corak deskripsi, karena menggunkan metode kualitatif sehingga membutuhkan penggambaran secara luas dalam laporannya dan harus memposisikan pembaca seolah-olah sebagai orang yang terlibat dalam penelitian (Sugiarto, 2015: 45).

Pengumpulan data dalam penelitian kualitatif perlu diperhatikan, sebab kualitas riset sangat tergantung dari kualitas dan kelengkapan data yang telah didapatkan. Pertanyaan yang selalu diperhatikan dalam pengumpulan data adalah apa, dimana, kapan, dan bagaimana. Penelitian kualitatif biasanya bertumpu pada trianggulasi data yang diperoleh dari tiga metode yaitu interview, participant observation, dan analisis dokumen (document record) (Marshall, \& Rossman, 1999). 


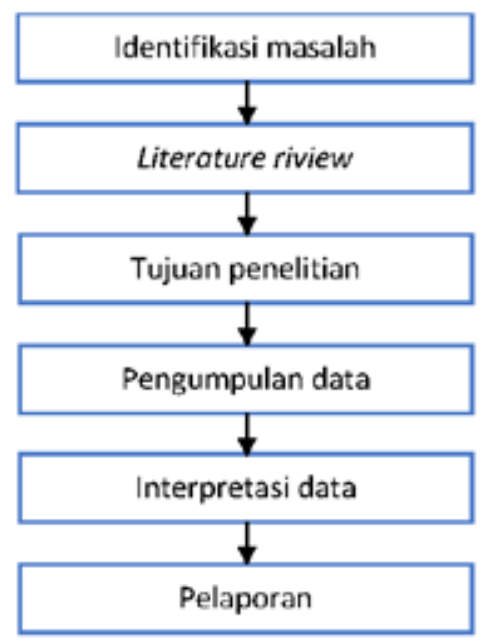

Gambar 2. Tahapan Penelitian Kualitatif (Raco, 2010: 19)

Pertama, interview, bertujuan untuk mencatat opini, perasaan, emosi, dan hal lain berkaitan dengan individu yang ada dalam organisasi. Interview dilakukan agar peneliti memperoleh data yang lebih banyak sehingga peneliti dapat memahami situasi/kondisi sosial dan budaya melalui bahasa dan ekspresi pihak yang diinterview dan dapat melakukan klarifikasi atas hal-hal yang tidak diketahui (Seidman, 2006). Kedua, participant observation, dilakukan dengan mengamati (observasi) secara langsung perilaku individu dan interaksi dalam setting penelitian. Maka dari itu, peneliti harus terlibat langsung dalam kehidupan sehari-sehari subyek yang dipelajari. Ketiga, analisis dokumen, hal ini merupakan bukti unik dalam studi kasus yang tidak ditemui dalam interview dan observasi. Sumber ini merupakan sumber data yang dapat digunakan untuk mendukung data dari observasi dan interview. Selain itu, telaah terhadap catatan organisasi dapat memberikan data tentang konteks historis setting organisasi yang diteliti. Sumber datanya dapat berupa catatan administrasi, surat-menyurat, memo, agenda dan dokumen lain yang relevan (Fitrah \& Lutfiyah, 2017).

Proses penelitian kualitatif, rancangan penelitian kualitatif diibaratkan oleh Bodgan (1982), seperti orang piknik, artinya ia baru tahu tempat yang akan dituju, namun tentu belum tahu pasti apa yang ditempat itu. Ia akan tahu setelah memasuki obyek dengan cara membaca informasi dari berbagai sumber baik tertulis, gambar, dan sebagainya. Maka, ia belum tahu apa yang akan dituju 
, dan ia akan tahu setelah melihat fenomenanya ia melihat, mengamati dan menganalisis dengan serius. Berdasarkan ilustrasi ini, dapat dikemukakan bahwa walaupun peneliti kualitatif belum memiliki masalah/keinginan yang jelas, tapi dapat langsung memasuki obyek/lapangan. Setelah peneliti masuk dalam obyek ia merasa asing akan obyeknya. Pada tahap inilah muncul orientasi/deskripsim dengan grandtour wuestion. Pada tahap ini peneliti mendeskripsikan apa yang dilihat, didengar, dirasakan, dan ditanyakan. Ia baru mengenal serba sepintas terhadap informasi yang diperolehnya.

Proses tahap selanjutnya dapat disebut tahap reduksi/fokus. Pada tahap ini peneliti mereduksi segala informasi yang telah diperoleh pada tahap pertama. Peneliti mereduksi data harus berfokus pada masalah tertentu saja agar tidak universal. Tahap reduksi ini peneliti menyortir data dengan cara meimilih data yang menarik, penting, berguna dan baru. Kemudian dari reduksi data ini akan dikelompok menjadi sebagai fokus penelitian. Tahap selection (data display) peneliti menguraikan fokus yang telah ditetapkan menjadi lebih rinci, setelah itu melakukan analisis data yang mendalam dari data dan informasi yang diperoleh, sehingga peneliti dapat menemukan tema/topic dengan merekontruksi data yang diperoleh menjadi suatu bangunan pengetahuan, hipotesis atau ilmu yang baru (Milles \& Huberman, 1994).

Dalam proses pemilihan data pada setiap tahapan harus dilakukan secara sirkuler/berulang-ulang dengan dengan berbagai cara dan berbagai sumber. Peneliti mencandra kembali terhadap kesimpulan yang telah dibuat. Apakah kesimpulan dibuat itu kredibel atau tidak. Untuk memastikan kesimpulan yang telah dibuat, maka peneliti masuk lapangan lagi, mengulangi pertanyaan dengan cara dan sumber yang berbeda, tetapi tujuannya sama, sehingga kesimpulan tadi diyakini memiliki kredibilitas yang tinggi dan pengumpulan data dinyatakan selesai. 


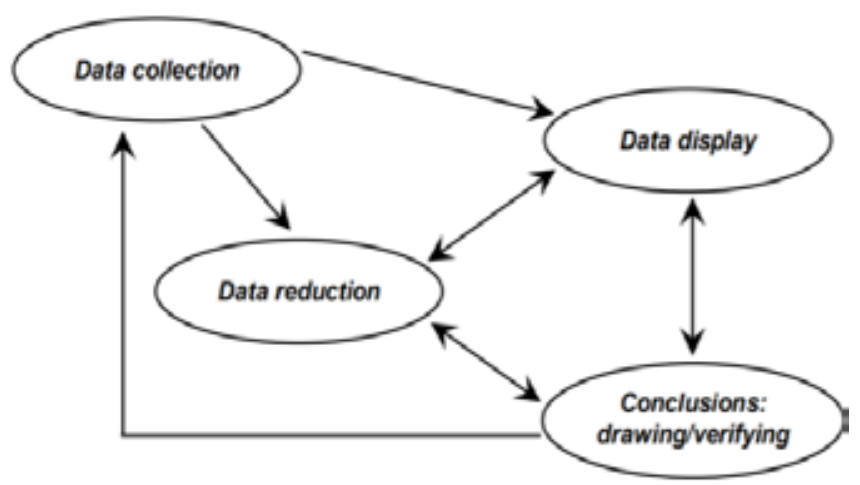

Gambar 3. Kompenan Analisis data (Miles \& Huberman, 1994)

Penelitian kualitatif di dalamnya tidak ada pendekatan yang tunggal dalam menganalisis data. Pemilihan metode sangat tergantung pada research questions (Baxter \& Chua, 1998); research strategies dan theoretical framework (Glaser \& Strauss, 1967). Untuk melakukan analisis, peneliti perlu menangkap, mencatat, menginterpretasikan dan menyajikan informasi. Peneliti perlu memperhatikan bahwa dalam penelitian kualitatif, analisis data tidak dapat dipisahkan dari data collection dan archival sources, analisis data sifatnya harus segera dilakukan agar dapat menentukan pengumpulan data berikutnya.

Menurut Miles \& Huberman ada tiga jenis kegiatan dalam analisis data yaitu reduksi data, display data, dan conclusions. Adapun gambaran kegiatannya sebagai berikut: 
Humanika, Kajian IImiah Mata Kuliah Umum, Vol. 21. No. 1. (2021), 33-54

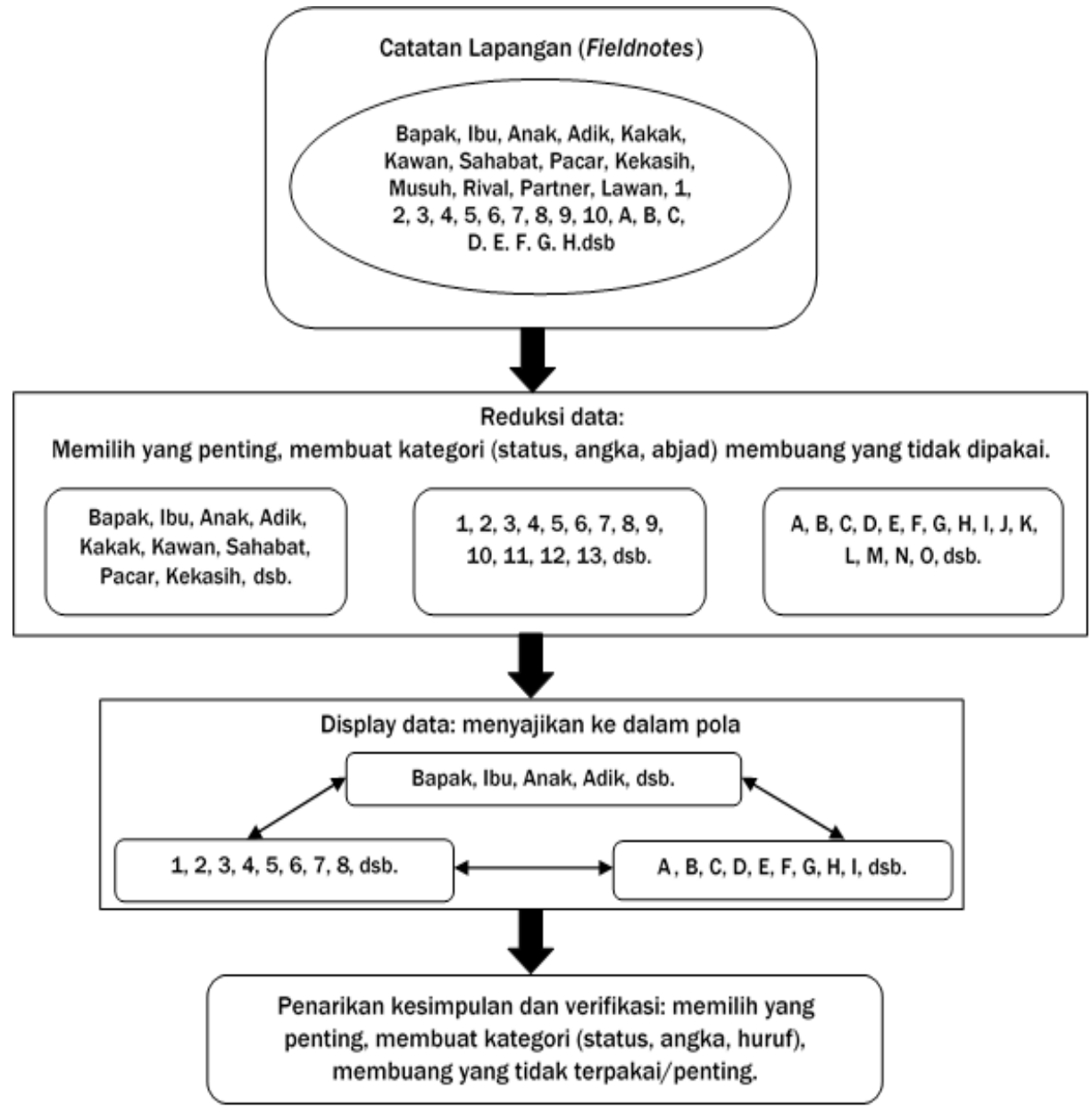

Gambar 4. Gambaran Kegiatan Analisis Data

Reduksi data berarti merangkum, memilih hal-hal pokok, memfokuskan pada hal-hal yang penting, mencari tema dan pola serta membuang yang dianggap tidak perlu. Artinya data yang telah direduksi akan memberikan sebuah gambaran yang lebih jelas, dan mempermudah peneliti untuk melakukan pengumpulan data berikutnya, dan mencari lagi bila diperlukan. Dalam reduksi data dapat pula dibantu dengan alat-alat elektronik dengan memberikan aspekaspek tertentu guna mempermudah proses reduksi data.

Data display (penyajian data) tahap setelah reduksi data, hal ini dilakukan dalam bentuk uraian/deskripsi, bagan, hubungan antar kategori dan sejenisnya. 
Miles \& Huberman (1994) menjelaskan "the most frequen from of display data for qualitative research data in past has been narrative tex". Artinya yang paling sering digunakan dalam menyajikan data penelitian kualitatif bersifat naratif. Penyajian data bertujuan untuk mempermudah dan memahami tentang yang terjadi. Bila hipotesis yang diberikan selalu didukung oleh datanya yang dilapangan sehingga akan menjadi grounded. Teori ini ditemukan secara induktif, berdasarkan datadata yang ditemukan dilapangan dan diuji melalui pengumpulan data secara terus menerus.

Menarikkesimpulandanverifikasimerupakanpengampilandaripermulaan pengumpulan data, alur, sebab-akibat/kausalitas dan proporsi-proporsi lainnya. kesimpulan dalam penelitian kualitatif mungkin dapat menjawab rumusan masalah sejak awal, tetapi mungkin juga tidak, karena seperti telah dikemukakan bahwa masalah dan rumusan masalah dalam penelitian kualitatif masih bersifat sementara dan akan berkembang setelah penelitian berada dilapangan. Namun, kesimpulan dalam penelitian kualitatif diharapkan akan memunculkan temuan baru (novelty) yang sebelumnya belum pernah ada. Temuan berupa deskripsi/ teori dari suatu obyek yang sebelumnya masih belum jelas sehingga setelah diteliti menjadi lebih jelas (Barrett \& Twycross, 2018).

Tantangan bagi analisis data penelitian kualitatif adalah bagaimana memberikan arti pada data yang begitu banyak. Data dapat dianalisis dengan langkah-langkah sebagai berikut: (1) Membaca berkali-kali data yang diperoleh dan memperhatikan untuk mengurangi informasi yang berulangulang. (2) Melihat signifikansi/pentingnya data yang diperoleh, contoh pertanyaannya adalah Apakah yang penting dari informasi yang disampaikan? (3) mengklasifikasi/coding data yang memiliki keserupaan/kecocokan dengan data lain. (4) Mencari pola/tema yang mengikat pikiran yang satu dengan lainnya. (5) Mengkonstruksi framework untuk mendapatkan esensi dari apa yang disampaikan oleh data yang diperoleh. Langkah tersebut, tidak ada yang baik atau tidak namun, gunakanlah intelektual, keahlian, dan kemampuan peneliti yang sangat menentukan perolehan hasil yang baik (Raco, 2010; Silverman, 1997).

Menurut Creswell (2008) cara pengkodean analisis data adalah (1) Cari arti keseluruhan, pilihlah yang paling penting dan paling singkat. (2) Tanyakan apa yang disampaikan oleh data tersebut dan cari arti yang terkandung dalam informasi itu. (3) Buatlah catatan setiap statement, coding dapat juga dibuat dengan memilih-memilah topic sesua dengan setting dan konteks, perspektif partisipan, cara berpikir partisipan, proses, aktifitas, strategi, hubungan dan 
struktur sosial. (4) Setelah pengkodean dilanjutkan dengan membuat daftar dari kode yang telah dibuat, dengan cara sendirikan kode yang memiliki arti sama. Hilangkan yang redundant, koding nantinya akan makin kecil dan kecil atau mengkerucut yang nantinya akan membentuk tema/pola-pola. Fungsi kode adalah membuat ide/gagasan utama. (5) Tentukan lima hingga tujuh tema/pola, ada beberapa tipe tema, ada tema biasa yaitu tema yang sudah diduga oleh peneliti. Ada tema yang muncul diluar dugaan sebelumnya yaitu yang muncul saat analisis data/saat penelitian dibuat ada juga tema yang sulit diklasifikasikan.

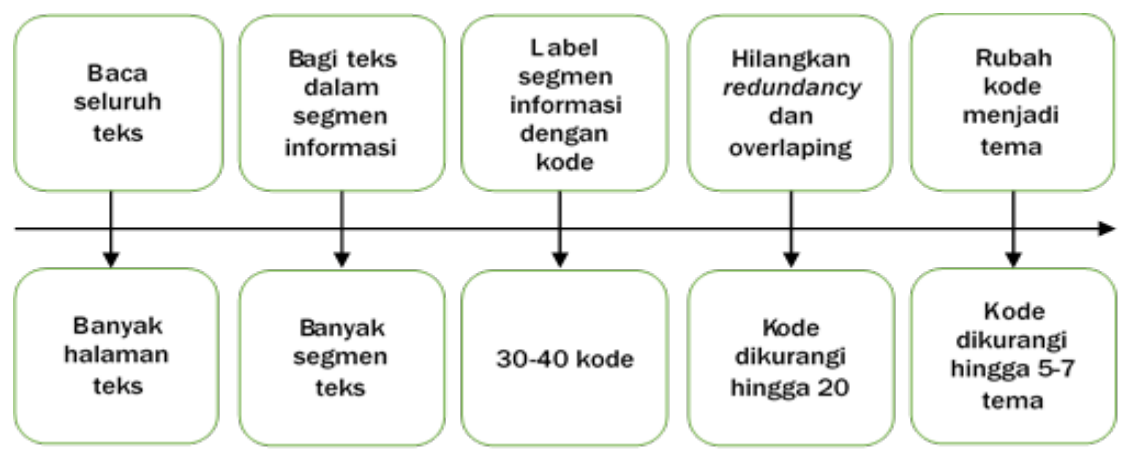

\section{Gambar 5. Proses Analisis (Proses Model Pengkodean)}

Tema dan pola adalah hal yang sama, perbedaannya sangat kecil, maksudnya pola merujuk kepada deskripsi dari temuan; sedangkan tema menunjuk terhadap bentuk topic. Tema inilah yang nantinya dianggap sebagai penemuan baru, kemudian diinterpretasikan dengan merujuk pada penelitianpenelitian sebelumnya, sehingga tema dapat menjadi dasar untu refleksi peneliti.

Contoh di atas menggambarkan hasil klasifikasi atau coding yaitu: keputusan yang sulit, empati, pengetahuan tentang kurikulum, memiliki pendidikan yang cukup. Coding ini kemudian diperoleh beberapa tema utama yaitu keputusan, pengetahuan. Keputusan dan pengetahuan ini adalah tema-tema yang mengartikan kebijaksanaan. Artinya kebijaksanaan seorang pemimpin, berdasarkan hasil analisa teks, ditentukan oleh factor keputusan dan pengetahuan. Inilah findings dari penelitian tentang kebijaksanaan menurut pimpinan sekolah. Alasan pimpinan disebut bijaksana adalah karena kemampuannya untuk membuat keputusan dan pengetahuan yang dimilikinya, keputusan dan pengetahuan tersebut statement of meaning. 
Tabel 2. Contoh Analisis Coding (Kebijaksanaan Menurut Pimpinan Sekolah)

\begin{tabular}{|c|c|c|}
\hline Koding & $\begin{array}{l}\text { Partisipan: menurut pengalaman saya, } \\
\text { kebijaksanaan sebagai kepala sekolah akan } \\
\text { Nampak sangat jelas pada saat melakukan } \\
\text { dan membuat keputusan/kebijakan. Harus } \\
\text { diingat sebagai seorang pemimpin harus selalu }\end{array}$ & Tema \\
\hline $\begin{array}{l}\text { Keputusan } \\
\text { yang sulit }\end{array}$ & $\begin{array}{l}\text { membuat keputusan. Meskipun keputusan } \\
\text { yang saya maksud merupakan keputusan yang } \\
\text { sulit, sebab semua alternatifnya nampak sudah } \\
\text { buntu. Nah, disini sebagai seorang pemimpin } \\
\text { dituntut untuk membuat keputusan yang satu } \\
\text { pihak tidak merugikan lembaga tetapi dipihak }\end{array}$ & Keputusan \\
\hline Empati & $\begin{array}{l}\text { lain dia harus melihat dampak keputusan } \\
\text { yang telah dibuat bagi para anggota dan coba } \\
\text { menempatkan diri sebagai orang yang kena } \\
\text { korban dari keputusan tersebut. }\end{array}$ & \\
\hline $\begin{array}{l}\text { Pengetahuan } \\
\text { tentang }\end{array}$ & $\begin{array}{l}\text { Partisipan: seorang pemimpin sekolah } \\
\text { haris memahami mengenai kurikulum dan } \\
\text { manajemen sekolah. Pengetahuan ini adalah }\end{array}$ & Pengetahuan \\
\hline kurikulum & $\begin{array}{l}\text { penting bagi si pemimpin sehingga dia } \\
\text { dapat mengarahkan sekolah atau lembaga } \\
\text { pendidikan yang dipimpinannya ketujuan } \\
\text { yang benar dan dapat mencapai sasaran } \\
\text { yang dikehendaki. Hal ini berarti bahwa }\end{array}$ & \\
\hline $\begin{array}{l}\text { Memiliki } \\
\text { pendidikan } \\
\text { yang cukup }\end{array}$ & $\begin{array}{l}\text { seorang pemimpin sekolah harus memiliki } \\
\text { pengetahuan yang cukup tentang pendidikan, } \\
\text { karena untuk menjadi pemimpin sekolah ada } \\
\text { persyaratan akademik yang harus dituntut. } \\
\text { Namun, pengetahuan tentang bagaimana } \\
\text { menjalankan suatu lembaga pendidikan juga } \\
\text { sering diperoleh melalui perkumpulan atau } \\
\text { pertemuan para pemimpin sekolah entah } \\
\text { dalam bentuk rapat atau pertemuan dan } \\
\text { pelatihan serta tukar pengalaman. }\end{array}$ & \\
\hline
\end{tabular}


Dalam menentukan kredibelitas data penelitian kualitatif, lebih menekankan dengan istilah autentisitas dari pada validitas. Sebab autentisitas lebih signifikan memberikan deskripsi, keterangan, informasi yang adil dan jujur. Artinya hasil data yang diperoleh dan diinterpretasikan harus tepat, sehingga deskripsi yang ditulis berdasarkan dari data riil bukan hasil dari karangan peneliti sendiri. Penelitian kualitatif dalam memvaliditas data hasil penelitian harus menentukan akurasi dan kredibelitas hasil dengan menggunakan strategi yang tepat, seperti member checking atau trianggulasi.

Teknik yang digunakan dalam menganalisis data dalam penelitian kualitatif ada beberapa jenis, tujuannya untuk menjamin akurasi dan kredibel hasil penelitian diantaranya yaitu: (1) Trianggulasi data; maksudnya menggunakan bermacam-macam data, menggunakan lebih dari satu teori, beberapa teknik analisa, dan melibatkan lebih banyak peneliti dalam mengolah hasil penelitian. (2) Member checking; berarti hasil data wawancara dikonfrontasikan kembali dengan partisipan untuk membaca, mengoreksi, atau memperkuat hasil data yang dibuat oleh peneliti. (3) Auditing; berarti menunjukkan peran ahli dalam memperkuat hasil penelitiannya, auditing biasanya mengandalkan keterlibatan pihak luar dalam mengkonfirmasi/ mengevaluasi penelitian, dan yang biasa dipertanyakan oleh auditor ialah, apakah hasil benar-benar bersifat alamiah dan bertumpu pada kondisi/situasi setempat (grounded); apakah pengambilan kesimpulan logis; apakah strategi yang digunakan sungguh-sungguh meningkatkan kredibilitas (Williams \& Moser, 2019; Raco, 2010).

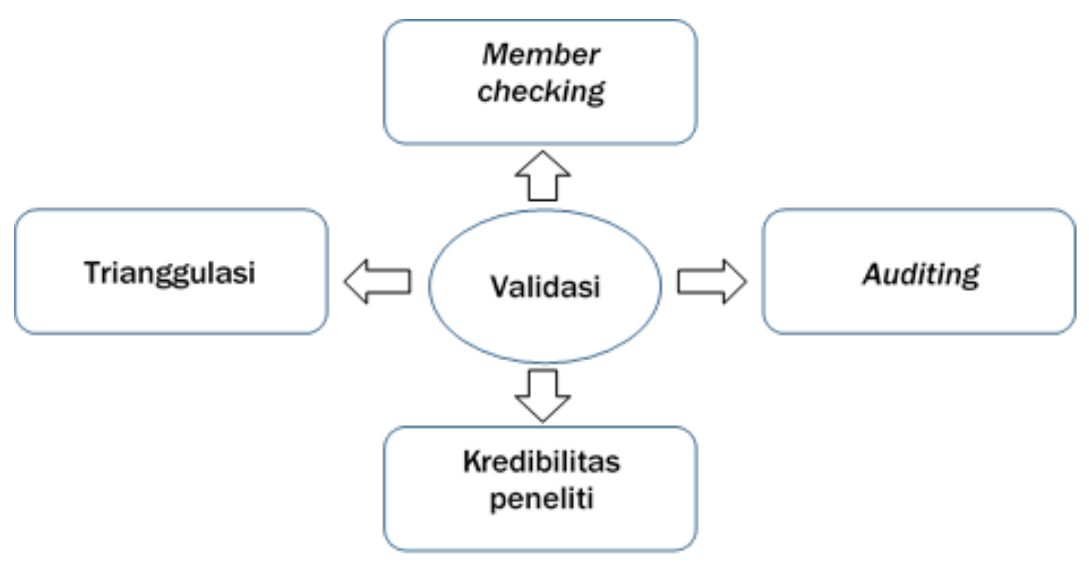

Gambar 7. Validitas Penelitian Kualitatif 
Reliabilitas dalam penelitian kualitatif dapat dilihat dari aspek: ketajamannya, observasi, analisis teks, interview, dan transcript dari perolehan data yang didapatkan dari lingkungan alamiah. Dengan demikian, hal yang terpenting perlu diperhatikan adalah (1) mengenai interview; dimana partisipan harus mengerti pertanyaan-pertanyaan atas cara yang sama sehingga jawabannya dapat dicoding tanpa kemungkinan ketidakpastian. (2) nilai kebenaran (truth value); artinya deskripsi dari pengalaman partisipan memang benar-benar yang dialaminya (natural/alamiah). (3) bahan hasil wawancara; dipastikan harus sesuai dengan apa yang dikatakan. Maka, reliabilitas dalam penelitian kualitatif ada kaitannya dengan observasi, sehingga peneliti harus benar-benar menguasai lapangan, mengetahui persis apa yang terjadi dilapangan, serta mengetahui budaya yang diteliti (Manaf, 2015).

\section{Mengapa Perlu Menggunakan Penelitian Kualitatif}

Ada alasan-alasan tertentu yang mendorong mengapa perlu menggunakan penelitian kualitatif dalam melakukan kegiatan ilmiah dan mengungkap suatu fenomena/fakta serta mencari solusi/jawaban dalam mengatasi masalah, alas an tersebut diantaranya: (1) data yang diperoleh sangat mendasar, sebab berdasarkan fakta, peristiwa dan realita yang ada, jadi bukan rekayasa peneliti. (2) hasil penelitian dan pembahasannya mendalam, terpusat karena datanya digali secara mendalam. Keterlibatan peneliti dalam penelitian yang cukup lama dan memperhitungkan semua factor mengitarinya seperti halnya ideologi, politik, ekonomi, pendidikan, dan budaya menunjukkan kedalaman makna yang pada akhirnya dihasilkan lewat metode kualitatif. (3) sifatnya terbuka dan lebih dari satu pandangan dalam hal ini pandangan dan informasi dari partisipan. Jadi, hasil penelitian tidak diasumsikan oleh peneliti diawal penelitian, namun diperoleh dari partisipan dan dianalisa oleh peneliti, hal ini menunjukkan aspek demokrasinya dari metode kualitatif ini, sehingga peneliti tidak menentukan dan mengasumsikan hasilnya dari awal. (4) sifatnya yang realistis dari metode ini. Bagi peneliti yang menggunakan metode ini ia telah percaya kepada dinamika dan proses. Manusia dan alam lingkungan hidup, berkembang dan berubah dari waktu ke waktu. Realita yang tidak diasingkan yaitu bahwa semuanya berubah. Proses ini tidak akan pernah selesai, karena sangat diakomodir oleh metode kualitatif (Raco, 2010; Sugiarti, Andalas \& Setiawan, 2020). 
Keuntungan lain dalam menggunakan metode penelitian kualitatif ini adalah bila ingin mengetahuai sesuatu secara lebih mendalam. Bila gejala kurang diketahui dan masih belum jelas. Bila gejala tidak dapat diukur. Tambahan pula bila penelitian tidak dapat dibuat dengan eksperimen di laboratorium. Metode kualitatif ini benar-benar menempatkan/memposisikan manusia sebagaimana mestinya. Sebab manusia adalah makhluk yang sangat luhur, manusia tidak hanya berada, akan tetapi mengerti akan keberadaannya, dapat berbica, berpikir dan dapat menentukan masa depannya. Manusia adalah benar-benar diperlukan sebagai subyek. Manusia tidak dapat dijadikan sebagai obyek dan dikerdilkan oleh angka-angka. Manusia benar-benar makhluk yang memiliki kaya arti, sehingga kekayaan inilah dapat diteliti dan dimengerti. Jadi kunci dari penelitian kualitatif terletak pada peran peneliti itu sendiri, agar penelitian yang dilakukannya jauh lebih bagus untuk menjadi sebuah temuan baru/teori-teori baru untuk menjawab solusi masalah yang dihadapi, serta untuk menjawab tantangan perkembangan zaman.

Penelitian kualitatif bila digunakan dalam bidang pendidikan memiliki tujuannya tertentu yaitu untuk memahami dan mengeksplorasi secara mendalam dan empati proses, aktivitas, pola-pola, model, prosedur, kultur, pendekatan, metode, strategi, penilaian, dan evaluasi dalam ranah pendidikan. Artinya peneltian kualitatif bila digunakan dalam pendidikan berguna untuk menemukan solusi atau teori-teori baru dalam dunia pendidikan (Siddiq \& Choiri, 2019).

\section{Kesimpulan}

Penelitian kualitatif merupakan studi yang meneliti suatu kualitas hubungan, aktivitas, situasi, atau berbagai material. Artinya penelitian kualitatif lebih menekankan pada deskripsi holistik, yang dapat menjelaskan secara detail tentang kegiatan atau situasi apa yang sedang berlangsung daripada membandingkan efek perlakuan tertentu, atau menjelaskan tentang sikap atau perilaku orang. Teknik pengumpulan data dari penelitian kualitatif yaitu observasi, wawancara dan analisis dokumen. Sedangkan dalam menganalisis datanya menggunakan teknik trianggulasi data, member checking, dan auditing, serta teknik analisis data menurut Miles \& Huberman yaitu reduksi data, display data, dan conclusions. Dalam analisis data tidak dapat dipisahkan dari data collection dan archival sources. 


\section{Daftar Pustaka}

Barrett, D., \& Twycross, A. (2018). Data collection in qualitative research. Evidence-Based Nursing, 21 (3), 63-64. http://dx.doi.org/10.1136/eb-2018102939.

Basrowi \& Suwandi. (2009). Memahami penelitian kualitatif. PT. Rineka Cipta.

Baxter, J., A., \& Chua W., F. (1998). "Doing field research: practice and meta】 theory in counterpoints." Journal of Management Accounting Research, 10, 69087. https://ssrn.com/abstract $=137273$.

Baxter, P., \& Jack, S. (2008). Qualitative case study methodology: study design and implementation for novice researchers. The Qualitative Report, 13 (4), 544-559. http://www.nova.edu/ssss/QR/QR13-4/baxter.pdf.

Bodgan, R., C., \& Biklen, S., K. (1982). Qualitative research for education, an introduction to theories and method. Pearson.

Bungin, B. (2001). Metode penelitian kualitatif: Aktualisasi metodologis ke arah ragam varian kontemporer. Rajawali Press.

Chariri, A. (2009). "Landasan filsafat dan metode penelitian kualitatif", Paper disajikan pada Workshop Metodologi Penelitian Kuantitatif dan Kualitatif, Laboratorium Pengembangan Akuntansi (LPA), Fakultas Ekonomi Universitas Diponegoro Semarang.

Creswell, J. (2008). Educational research, planning, conducting, and evaluating quantitative and qualitative research. Pearson.

Creswell. J. W. (1994). Research design qualitative $\mathcal{E}$ quantitative approaches. Sage

Daliman, A. (2014). Metode penelitian sejarah. Ombak.

Denzin, N. K., \& Lincoln, Y. S. (Eds.). (1994). Handbook of qualitative research. Sage Publications, Inc.

Fitrah \& Lutfiuyah. (2017). Metodologi penelitian: Penelitian kualitatif, tindakan kelas $\mathcal{E}$ studi kasus. CV Jejak Publisher.

Frankel. J. R. \& Wallen. N. E. (1998). How to design and evaluate research in education (Second Edition). Mc. Graw Hill Inc.

Glaser, B., \& Strauss, A. (1967). The discovery of grounded theory: strategies for qualitative research. Aldine Press.

Heidegger, Martin. (1961). An Introduction to Metaphysics (asli: Einf hrung in die Metaphysik, translate by Ralph Manheim). Anchor Book. 
Hennink, M., Hutter, I., \& Bailey, A. (2020). Qualitative research methods. Sage Pub.

Mamik. (2015). Metodologi kualitatif. Sidoarjo: Zifatama Publisher.

Manaf, A. (2015). Penelitian pendidikan: pendekatan kualitatif. Kalimedia.

Marshall, C., \& Rossman, G. (1999). Designing qualitative research. Sage Pub.

Martin, P. Y., \& Turner, B. A. (1986). Grounded theory and organizational research. Journal of Applied Behavioral Science, 22 (2), 141-157. https://doi. org/10.1177/002188638602200207.

Merriam, S., B., \& Grenier, R., S. (2019). Qualitative research in practice: examples for discussion and analysis. Jossey-Bass.

Miles, M. B., \& Huberman, A. M. (1994). Qualitative data analysis: An expanded sourcebook. Sage.

Neuman. W. L. (2006). Sosial research method: qualitative and quantitative approaches. (Third Edition). USA.

Raco, J., R. (2010). Metodo penelitian kualitatif. Grasindo

Ramberg, Bjørn and Gjesdal, Kristin. (2014). "Hermeneutics", Stanford Encyclopedia of Philosophy (Winter 2014 Edition), Edward N. Zalta (ed.), https://plato.stanford.edu/archives/win2014/entries/hermeneutics/.

Rijali, A. (2018). Analisis data kualitatif. Jurnal Alhadharah, 17(33), 33-45. http://dx.doi.org/10.18592/alhadharah.v17i33.2374.

Sarmanu. (2017). Dasar metodologi penelitian kuantitatif, kualitatif, dan statistik. Airlangga University Press.

Seidman, I. (2006). Interviewing as qualitative research. Teachers College.

Setiawan, J., \& Anggito, A. (2018). Metodologi penelitian kualitatif. CV Jejak Publisher.

Sidiq, U., \& Choiri, M. (2019). Metode penelitian kualitatif di bidang pendidikan. CV Nata Karya.

Silverman, D. (1997). Qualitative research. Theory, method and practice. Sage Pub, Inc.

Sugiarti, Andalas, E., F., \& Setiawan, A. (2020). Desain penelitian kualitatif sastra. UMM Press.

Sugiarto, E. (2015). Menyusun proposal penelitian kualitatif: skripsi dan tesis. Suaka Media.

Sugiyono. (2011). Metodologi penelitian kuantitatif kualitatif dan REDD. Alfabeta. 
Suryani \& Hendryadi. (2015). Metode riset kuantitatif teori dan aplikasi. Prenadamedia Group.

Suwendra, I., W. (2018). Metodologi penelitian kualitatif dalam ilmu sosial, pendidikan, kebudayaan dan keagamaan. Nilacakra Publishing House.

Walidin, W., Saifullah, \& Tabrani. (2015). Metodologi penelitian kualitatif $\mathcal{E}$ grounded theory. FTK Ar-Raniry Press.

Williams, M., \& Moser, T. (2019). The art of coding and thematic exploration in qualitative research. International Management Review, 15, 45. https:// www.semanticscholar.org/.

Yusanto, Y. (2019). Ragam Pendekatan Penelitian Kualitatif. Journal of Scientific Communication, 1(1), 1-13. http://dx.doi.org/10.31506/jsc. v1i1.7764. 
Humanika, Kajian IImiah Mata Kuliah Umum, Vol. 21. No. 1. (2021), 33-54 